\title{
Explanations for religious influence on adolescent sexual behavior in Brazil: direct and indirect effects
}

\author{
Ana Paula de Andrade Verona*
}

\begin{abstract}
Religion is becoming an important and highly present factor in the lives of many adolescents and young adults in Brazil. In addition to creating more space for them to maintain close relationships and participate actively in a religious environment, some religions have promoted the dissemination of clearer standards and objectives, as well as punitive sanctions, with respect to many aspects of their younger followers' lives, including their sexual behavior. This article examines how religion can affect, direct and indirectly, the sexual behavior of Brazilian adolescents. The main objective of this study is to look for a connection between Christian Smith's theoretical framework, which suggests several mechanisms through which religion can influence the lives of American adolescents, and ethnographic studies conducted in Brazil, as well as quantitative works that have brought attention to social and demographic consequences of recent religious transformations. Even though there is limited empirical evidence as to how the mechanisms of religious involvement work in Brazil, this study concludes that each of Smith's pathways can also be used to explain potential effects of religion on sexual behavior of Brazilian adolescents. This research should encourage empirical studies on such effects in Brazil. Besides the importance of examining the impact of the recent transformations in Brazil religious landscape on demographic phenomena, this topic deserves further consideration from Brazilian demographers because religion is a primary socialization agent of adolescents, and sexual activity is a sphere of human behavior of high importance in its religious applicability.
\end{abstract}

Keywords: Religion. Adolescent sexual behavior. Mechanisms of influence. Direct and indirect effects.

\section{Introduction}

Studies on the association between religion and demographic phenomena are part of a research agenda that has been substantially developed over the last three decades. These studies (theoretical and empirical), which are almost exclusively conducted in the United States, have frequently shown that religion may promote positive outcomes, very often related to healthier behaviors and lifestyles among religiously engaged people (ELLISON; LEVIN, 1998; REGNERUS, 2003). Some other researches, however, also bring evidence of negative impacts (KRAUSE;

\footnotetext{
${ }^{*} \mathrm{PhD}$ in Demography. Post-doctorate at Cedeplar/Universidade Federal de Minas Gerais - UFMG.
} 
ELLISON; WULFF, 1998; KRAUSE; ELLISON, 2009).

Many authors have analyzed among Americans the association between religious involvement and drug, tobacco, and alcohol abuse (COCHRAN, 1993), as well as between religion and youth delinquency and violence (EVANS et al., 1995), infant and adult mortality (KOENIG, MCCULLOUGH; LARSON, 2001; HUMMER et al., 2004), and its association with educational attainment and the labor market (REGNERUS, 2000, MULLER; ELLISON, 2001; GLANVILLE; SIKKINK; HERNANDEZ, 2008). Other researches have also investigated the relationship between religion and sexual initiation, age at marriage, contraceptive use, abortion, and fertility (WESTOFF; JONES, 1979; MOSHER; HENDERSHOT, 1984; PARKERSON; PARKERSON, 1988; GOLDSCHEIDER; MOSHER, 1988; THORNTON; CAMBURN, 1989; MCQUILLAN, 2004).

Some studies have examined the relationship between religion and demographic variables in Brazil (DECOL, 1999; HILL; CLELAND; ALI, 2004; ROHDEN et al., 2005; ALVES; NOVELLINO, 2006, WOOD; WILLIAMS; CHIJIWA, 2007; MCKINNON; POTTER GARRARD-BURNETT, 2008; MIRANDA-RIBEIRO et al., 2009; VERONA; REGNERUS, 2009; VERONA et al., 2010). The scientific production on this topic, however, is still quite limited, especially among Brazilian researchers.

Given the remarkable changes that Brazil has experienced in its religious landscape over recent decades (ANTONIAZZI, 2006), it is essential that Brazilian demographers begin to analyze more deeply the association between religion and demographic components and aspects (as suggested by MIRANDA-RIBEIRO et al., 2009; VERONA et al., 2010). In an attempt to contribute for the development of this topic, this article examines how religion can affect, direct and indirectly, the sexual behavior of Brazilian adolescents. The main objective of this study is to look for a connection between the theoretical framework of Christian Smith ${ }^{1}$ published in 2003, which suggests several mechanisms through which religion can influence the lives of American adolescents, and some ethnographic studies conducted in Brazil as well as quantitative works that have brought attention to potential social, demographic, economic, and cultural consequences of the recent religious transformation. More specifically, even if Smith (2003) does not try to explain a specific outcome of adolescents' lives, this paper intends to show that the mechanisms of religious influence suggested by him may be applied to study the impact of religion on adolescent sexual behavior in Brazil.

This article begins with a brief exposition about the main recent empirical changes in adolescent sexual and reproductive behavior in Brazil, calling attention to the importance of considering religion when analyzing such changes. Next, this paper mentions some explanations of the direct effects of religion on adolescent sexual behavior, including three main ways of influence that are expressed by aspects of moral order, religious sanctions, and consequences for deviance. Then, this study considers the indirect effects of religion, including pathways named as learned competences and social and organizational ties. In this section, we also present a conceptual model that summarizes how religion may, directly and indirectly, affect adolescent sexual behavior. Although this model is almost entirely based on the mechanisms

\footnotetext{
${ }^{1}$ Christian Smith is a sociologist of religion and his research focuses primarily on religion in modernity, adolescents, American evangelicalism, and culture. He is currently the Director of the Center for the Study of Religion and Society at the University of Notre Dame, a national Catholic university located in Notre Dame, Indiana, United States (Information available at http://www.nd.edu/ csmith22). The extensive scientific production of Christian Smith has been extremely important to improve the understanding of different connections between religion and the lives of American adolescents. Although a large body of empirical studies shows that religion often serves as a factor that influences adolescents' behavior and attitudes, Smith (2003, p. 17) emphasizes that "the existing theoretical explanations for these religious effects remain largely disjointed and fragmented" and his work titled Theorizing religious effects among American adolescents is particularly important since it formulates "a more systematic, integrated, and coherent account of religion's constructive influence in the lives of American youth" (SMITH, 2003, p. 17).
} 
of religious influence suggested by Smith (2003), it is created and introduced by this study to elucidate the potential religious effects on adolescent sexual behavior specifically among Brazilian adolescents. Lastly, this article brings a discussion section.

\section{Adolescent sexual behavior and religion in Brazil}

Brazil experienced large and rapid fertility declines over the period from 1960 to 2006, when the Total Fertility Rate (TFR) dropped from 6.3 to 1.8 children. During this process, age-specific fertility rates (ASFR) diminished substantially for all age groups in the reproductive span. However, the older age groups presented steeper declines, causing a concentration of fertility at younger ages (GUPTA; LEITE, 1999). Besides the unequal fertility decline across the reproductive age groups, the 1990's added a new factor that contributed to such a concentration: the rise of fertility rates among adolescent women, defined as the female population aged 15-19 (BERQUÓ; CAVENAGHI, 2005). Estimates from the Brazil DHS (Demographic and Health Survey) show that the ASFR for adolescents increased from 74 births per 1,000 women in 1986 to 86 in 1996.

The 2006 PNDS (Pesquisa Nacional de Demografia e Saúde - Demographic and Health National Survey) revealed a near stagnation (to 83 births per 1,000 women) of adolescent fertility in Brazil since 1996. The reasons teenage fertility increased and then stagnated in Brazil remain largely speculative, since it occurred simultaneously with historical facts that usually indicate the opposite outcome, such as increasing urbanization and education level and the almost universal knowledge of family planning methods or availability of contraception.

One of the most proximate determinants of fertility - age at first sexual intercourse - certainly plays an important role in this phenomenon, since the percentage of Brazilian adolescent women who report never having had sex decreased dramatically in 20 years: from 80 to 45 percent (between 1986 and 2006). Such a decline may indicate changes in attitudes about sexual intercourse, marriage, and childbearing in Brazil, which are traditionally "taught" through religious norms and values (PIERUCCI, 1978; JUAREZ, 1998).

Declining age at first sexual intercourse has been accompanied by a transformation in the Brazilian religious landscape, which has been marked by three associated phenomena: the end of Catholic dominance in the religious market, the significant growth of Pentecostalism (led by Protestant churches and then charismatic Catholic communities), and the growth of those who identify themselves as having no religion. Religion deserves further consideration when analyzing adolescent sexual behavior in Brazil not simply because this country has experienced tremendous changes in its religious landscape, but also both because religion is a primary socialization agent of adolescents, and because sexual activity is a sphere of human behavior of high importance in its religious applicability (REGNERUS, 2007).

Part of the few researches that have been conducted so far has pointed to traditional and Pentecostal Protestant churches as those that may be most effective at helping adolescent and young women avoid or postpone premarital sexual intercourse and childbearing in Brazil (MCKINNON; POTTER; GARRARD-BURNETT, 2008; VERONA; REGNERUS, 2009). This is an intriguing conclusion, since Pentecostal Protestantism has enjoyed overwhelming success in appealing to the poorest sub-populations (CHESNUT, 1997) where adolescent and premarital fertility are concentrated in Brazil.

\section{Direct effects}

According to social control theories of adolescent behavior, religion functions to encourage adolescents to avoid actions that they might otherwise have taken (ROHRBAUGH; JESSOR, 1975; DELAMATER, 1981; CROCKETT et al., 1996; REGNERUS, 2003, 2007; SMITH, 2003; HARDY; RAFFAELLI, 2003; ROSTOSKY et 
al., 2004). The influence of religion has been frequently seen as an inhibiting force, which may contribute to postponing, reducing or even restricting certain behaviors, such as premarital adolescent sexual activity.

Research on religious influence on sexual behavior usually notes two types of effects: direct and indirect. Religion as a social control against undesirable behaviors may be directly mediated in at least three different ways: (1) by making the individual sensitive and aware of norms, moral order issues, and standards of appropriate behavior; (2) by embedding the individual in "conventional activities and in an organized sanctioning network" (p. 137); and, (3) by offering an ideology that is based on the nature of the deity as a source of punishment and wrath (ROHRBAUGH; JESSOR, 1975).

\section{Moral order}

The church, a socialization agent traditionally held responsible for the prescription of values and standards of sexual behavior, may play an important role in shaping sexual decision-making among adolescents and young adults. The work of Christian Smith (2003), formulates an integrated account of religion's constructive influence in the lives of American adolescents and helps elucidate this idea. This author suggests pathways, aggregated around the dimension of moral order, through which religion may act directly. He considers three factors in such a dimension: moral directives, role models, and spiritual experiences. According to Smith (2003), these factors promote particular normative ideas of what is good and bad, right and wrong, worthy and unworthy, and so on, thus guiding human consciousness, choice, and action. As pointed out by the author, these factors are believed to exist apart from and above human decisions, preferences, and desires.
The first factor suggested by Smith (2003) is defined as cultural moral directives of self-control and personal virtue that are internalized by young adults, who use them to guide their life choices and engage in appropriate conduct. Most religious groups articulate proscriptive values, distinguishing desirable behavior from undesirable behavior (e.g., sexual promiscuity, substance use/abuse). Toward this end, one of the major concerns of some churches in Brazil, especially the Pentecostals, and Catholic charismatic communities, ${ }^{2}$ is the demonstration of Christian values in secular society (CLEARY, 2007). They place special emphasis on the sphere of intimacy, especially with regards to family, habits, and sexuality (PIERUCCI; PRANDI, 2000). Most studies about Pentecostalism emphasize its pietism and conservative values. Pentecostal practical theology, for instance, disapproves of a variety of types of secular pleasures, such as modern hairstyle or dress and the use of cosmetics and ornaments, and as expected, places a ban on premarital sexual intercourse and pregnancy (CHESNUT, 2003; MARIANO, 2004). Similarly, the Catholic charismatic movement combats promiscuous sexual behavior and offers support to young persons who desire to remain celibate until marriage (CLEARY, 2007).

Another example is the high value attached to marriage. Because it is so esteemed by some religious denominations in Brazil, both Catholicism (especially those churches influenced by the charismatic wave) and Pentecostal Protestantism establish doctrines against premarital and extramarital sex and try to teach mechanisms for resisting these temptations. Pentecostal Protestant churches have been very effective in spreading restrictions on extramarital sex, which has very often helped adherents prevent problems, such as family conflict and disruption (BURDICK, 1993; CHESNUT,

\footnotetext{
2 Catholic Charismatic Renewal (CCR) movement was introduced in Brazil in the early 1970s. Since then its popularity has sharply increased, making it the largest and most active Catholic lay movement in the country (and in most of Latin America as well) (VALLE, 2004; CHESNUT, 2003; PIERUCCI; PRANDI, 2000). The CCR is a revitalization movement in Brazil that resulted from at least one motivation: to compete with Pentecostal Protestantism. Many of the changes in discourse, lifestyle, the local participation, and the way of practicing the faith among Pentecostal Protestants are also prevalent in the Catholic charismatic movement in Brazil (CLEARY, 2007).
} 
2003). A study by Hill, Cleland and Ali (2004), for example, examined the association between religious affiliation and extramarital sex among men in Brazil. The authors found that non-evangelical men were significantly more likely to report having had extramarital partners as well as unprotected extramarital sex when compared with members of evangelical religions.

Protestant congregations seem also to provide moral guidance on adolescent pregnancy. McKinnon, Potter and Garrard-Burnett (2008) recently explored the relationship of Protestantism, fertility and family formation among adolescents aged 15 to 17 living in the Rio de Janeiro Metropolitan Region. The researchers noted that the odds of ever having had a live birth are substantially lower among adolescent women belonging to mainline Protestant and Pentecostal Protestant churches, than among Catholics, adjusted for key controls. They also found that adolescents who belonged to those churches were much more likely to be married than Catholics.

The second factor, role models, provides adolescents with examples of life practices shaped by religious moral orders. Some of these examples are constructive and may positively affect youth's attitudes and relationships. Many churches in Brazil (and in particular Protestant ones) have caught young people's attention recently, and, consequently, a significant number of young religious leaders have been in demand to work (generally on a volunteer basis) inside the church. Young religious leaders are, for instance, very popular in the organization of youth meetings and services (VERONA, 2010). They expected to teach values and attitudes, as well as provide other adolescents with examples of religious life practices to be emulated. Moreover, during conversion to charismatic religions in Brazil, for instance, young religious leaders generally take on the responsibility of nurturing the newly converted members. They do this, among other things, through strong emotional support and by setting examples inside the church (CLEARY, 2007).

The last factor regarding the moral directive dimension, spiritual experiences, may help to reinforce moral commitments among young adults by providing organizational contexts and cultural substance awarded by religion. Some examples of these experiences are a conversion experience, an answer to a prayer, and the witnessing of a miracle (SMITH, 2003). The presence of spiritual experiences has been widely observed in Brazil through the process of conversion to some Pentecostal and, more recently, neoPentecostal churches as well as Catholic charismatic communities. Conversion to these churches and communities very often holds the spiritual power to transform individuals' behavior and lifestyle (CHESNUT, 2003). Cleary (2007) explained that conversion means, to charismatic Catholics in Brazil, a new way of life, a commitment to new elements, very often associated with faith healing (a gift from the Holy Spirit). According to the author, conversion in the Catholic charismatic movement "is believed to bring about the reordering of social and religious attitudes in line with God's wishes" (CLEARY, 2007, p. 156).

\section{Sanctions}

Most research on religion and adolescent sexual decisions suggests that religion largely forbids certain actions. Religion is almost always associated with sexual conservatism, repression, abstinence, and general condemnation of things (REGNERUS, 2007). Individuals in religious communities, therefore, may conform to religious norms because they fear potential social sanctions (ELLISON; LEVIN, 1998). Consequently, religious norms are very often enforced via the possibility of negative sanctions for noncompliance.

Different authors emphasize that a religious regimen of forbiddance in some Pentecostal churches in Brazil is sustained by formal (e.g., rebukes from clergy) and informal (e.g., gossip and isolation by fellow followers) sanctions (MARIZ, 1994; VERONA, 2010). Burdick (1993), for instance, argued that certain religious sanctions may influence the lives and behaviors of Brazilian youth. He noted that 
courting is closely regulated in Pentecostal churches, such as the Assemblies of God, where premarital sex is considered a very serious sin. According to the author, "those who surrender to temptation [premarital sex] may be severely disciplined, even excluded from communion for a time, and may suffer the withdrawal of the Holy Spirit" (BURDICK, 1993, p. 131).

Verona (2010) noted similar religious sanctions in her field work in Pentecostal and renewed Protestant churches in Belo Horizonte, Brazil. According to her, when members transgress a particular norm or principle (including norms on premarital sexual behavior and childbearing), they are usually called out and disciplined, defined as a period of absence, when the follower has the opportunity to reflect on what he or she did and, eventually, to repent. In some churches, including renewed Baptist churches, the transgressor is actually more closely followed during the exclusion period. This type of exclusion is considered a punishment that can cause embarrassment among church members being disciplined, especially those in leadership positions and those who participate in any church activities.

\section{Consequence for deviance}

The violation of religious norms may generate psychological consequences of deviance, for instance, evoke feelings such as guilt, public embarrassment, or the expectation of divine punishment (ELLISON; LEVIN, 1998). According to many investigators, any given behavior or consequence will vary based on the degree of religious salience, which is measured "at least partially in terms of respondents' subjective assessments of the importance of religion to themselves" (WIMBERLEY, 1989, p. 127). For persons with a high degree of salience, the transgression of religious norms will likely have consequences associated with psychological distress, which can be a type of cognitive dissonance - a mental state characterized by an uncomfortable feeling generated when there is a contradiction between what an individual believes and how she or he behaves. (FESTINGER, 1962).
Adolescents and young adults who belong to religious congregations in Brazil that discourage or ban premarital sexual relationships, for instance, may experience some or all of the consequences mentioned above if they decide to violate these (and other) religious sexual norms. Verona (2010) mentioned some examples of the consequences of deviance when she perceived a feeling of guilt or regret on the part of some young women from Pentecostal churches and Catholic charismatic communities who had transgressed a particular religious value or norm related to sexual behavior. In the same way, evangelical pastors recounted stories in which young people displayed shame and fear of divine punishment for having gone against what the church recommends with regard to premarital sexual behavior.

\section{Indirect effects}

So far, this article suggests that religion may directly affect decisions through religious norms, sanctions for noncompliance, and consequences for deviance, such as feelings of fear and guilt. Nevertheless, the absence or lack of perception of direct religious effects does not mean that religion is not important (REGNERUS, 2003). Indeed, the most common way that religion influences human actions is through indirect influences, which are "unintentional social byproducts when religious people doing things for religious reasons facilitate other distinctive outcomes" (REGNERUS; SMITH, 2005, p. 24). Research on indirect religious influences always call attention to mechanisms or pathways by which religion may help bring about a desired outcome. The work of Christian Smith (2003) also suggests key factors or pathways through which religion may indirectly act. These are aggregated around two dimensions: learned competences and social and organizational ties.

\section{Learned competences}

Smith (2003, p. 20) argues that religion can strongly influence the lives of the young "by increasing their competence in skills and 
knowledge that contribute to enhancing their well-being and improving their life chances". He structured such learned competences into these three factors: community and leadership skills, cultural capital, and coping skills.

Community and leadership skills are acquired in religions or churches that offer organizational contexts where the young can observe, learn, and practice them. Most churches, for instance, are often in need of members to coordinate initiatives and serve on committees and programs. These practices may provide a religiously engaged youth with the opportunity to develop abilities and obtain different types of experience. Importantly, such skills are very often translated into contexts beyond religious activities, such as neighborhood organizations, professional and educational activities, among others (SMITH, 2003).

Regarding these skills, Mariz (1994) argued that because Protestant churches in Brazil very often consist of independent small groups, ordinary people may have ample opportunity to develop leadership skills. However, perhaps the most immediate way to learn and practice leadership skills at most Protestant churches is through "cell" meetings - weekly gatherings where a small group of five to 15 people meets to read the Bible, pray, worship and have a moment of communion with God. They almost always take place in members' homes and must be led by one of these members. Interestingly, many churches offer leadership courses to form these cells. Moreover, it is common that young people also lead "cells", or small worship groups, and teach children, teenagers or other young people. Others are pastors of youth groups and coordinate lectures and seminars (VERONA, 2010).

Conversely, some extremely large Protestant churches in Brazil, including some Pentecostals, are usually made up of various ministries that promote different activities among members. In this context, the roles of the leader and assistant leader are fundamental. They are extremely important in organizing activities that may contribute to the development of knowledge, skills and techniques.
The next factor, cultural capital, is defined as forms of knowledge, skills, and advantages that a person has, which can give him or her a higher status in society. It may be institutionalized in the form of educational qualifications (BOURDIEU, 1986). Cultural capital can be acquired and increased through religious support of engaging in certain activities and practices that are embodied as implicit knowledge and dispositions. Some religions are viewed as an alternative opportunity to obtain elements of cultural capital, which tend to work toward positive, constructive behavioral outcomes in children and adolescents' lives (SMITH, 2003). For example, in religious congregations children and adolescents very often have a chance to receive Biblical and musical education; they may also learn about history, geography, and major religious traditions. The acwuisition of cultural capital elements, when helping coordinate a religious workshop, assisting in a tutoring program, or learning to play a musical instrument, for instance, represents a useful capability that can positively affect adolescents' opportunities at school (REGNERUS, 2000; MULLER; ELLISON, 2001; GLANVILLE; SIKKINK; HERNÁNDEZ, 2008) and in the labor market, increasing their confidence and life chances.

Unlike traditional Catholics, Pentecostals have long been recognized in Brazil for their religious knowledge (BURDICK, 1993). Pentecostal Protestant churches in Brazil also provide youth with substantial musical education through participation in choirs and choruses, and opportunities to play musical instruments for worship. The stimulus for reading, speaking, forming opinions, and playing musical instruments may encourage Pentecostals to become literate and develop skills that can be useful in other aspects of their lives (MARIZ, 1994). They may, for instance, become talented adolescents and develop higher educational and professional aspirations. Consequently, they may want to avoid or postpone certain sexual or reproductive outcomes, such as premarital sex or childbearing, which could hold consequences and restrict better life opportunities. 
Some churches even offer professional courses, lectures about the labor market, and scholarships. Sunday schools, for example, often become an area for reading, learning and improving communication skills. They are common in Protestant churches, such as in Assemblies of God, and attract people of all ages. The teachings are based on Bible passages, which are frequently used as a conduit to discuss prevailing issues in the lives of teenagers and young adults (VERONA, 2010).

It is well known that one of the primary functions of religion is to help people deal with adversity. The last factor of the dimension of learned competences, coping skills, is acquired via the religious promotion of beliefs and practices that can help adolescents cope with difficult moments and emotions, and overcome conflicts and tragedies, including financial hardship. Some churches may offer these youths resources and beliefs to address, negotiate, and cope with different types of life problems. This support can come through the offering of different resources, such as prayer, counseling, forgiveness, and reconciliation (SMITH, 2003), as well as through encouraging the believer to change his or her behavior. Some changes include reducing the use of products that are harmful to one's health, such as alcohol and drugs (BRUSCO, 1995), and minimizing the risk of having extra-marital relations (BURDICK, 1993; HILL; CLELAND; ALI, 2004), of single motherhood (MARIZ, 1994) and of teenage pregnancy (MCKINNON; POTTER; GARRARD-BURNETT, 2008).

We know little about the potential effect of religious involvement on coping skills in Brazil. In one of the studies that exist to address this issue, Mariz (1994) investigated whether religion has any influence on people overcoming poverty in Brazil. According to her, because Pentecostal congregations put special emphasis on family life and strict sexual morality, a motivational strategy for coping with poverty may be observed, since a single-parent family is usually associated with greater instability and economic problems than a household where a couple is present. Mariz (1994) also argued that the moral doctrine of Pentecostalism may decrease the rate of single motherhood and broken marriages, indirectly avoiding the further lowering of the living standard among poor families. In order to illustrate how Pentecostal churches may deal with single motherhood, she mentions an interviewee, who was expelled from her Pentecostal church because she became a single mother.

Lastly, followers very often claim to experience economic improvement after their conversion to Protestant churches as a result of abstaining from alcohol and drug use. For this reason, they are able to save money to invest in cash crops, land, housing, and consumer durables, which can help in overcoming poverty (MARIZ, 1994; BRUSCO, 1995; POTTER; AMARAL; WOODBERRY, 2009).

\section{Social and organizational ties}

The last three factors of religious indirect effects explained by Smith (2003) are: social capital, network closure, and extra community links. As mentioned above, this set of factors is aggregated into the social and organizational ties dimension. In this dimension Smith discusses structures of relations that affect the opportunities and limitations that adolescents and young people may face.

Social capital refers to social relationships and institutional involvements that provide individuals with various kinds of resources that can facilitate action and be mobilized toward instrumental ends (COLEMAN, 1988). Among other things, the acquisition of social capital is possible through religion because it is a not a rigidly-age-stratified institution. According to Smith (2003), apart from educational institution, leisure and athletic activities, religion represents one of the few contexts in which teenagers have a chance to interact with people older than them. Intergenerational relationships, in turn, promote interactions based on trust and care among young people, and can become a valuable source of information, resources and opportunities (MULLER; ELLISON, 2001). 
The next factor, network closure, can be seen as an aspect of social capital and refers to relational networks that facilitate control of young persons by adults. According to Smith (2003), social networks constructed in church encourage positive practices among teenagers and young adults because these networks can involve people who care about them, thus establishing a valuable tool for supervision and control in young people's lives. Regarding this supervision, Burdick (1993) and Rohden et al. (2005) observed that Pentecostal parents, for instance, maintain strict authority over their daughters' relations with men in Brazil. They very often disapprove of extended courtships and marriage to non-crentes. ${ }^{3}$

Furthermore, social networks involving interactions between teenagers and sources outside of family, such as pastors, Sunday school teachers, leaders and the parents of friends at church, can reinforce a paternal influence in the life of adolescents. This is because parents usually have access to these church members, who can be a source of information and help (VERONA, 2010). In addition, many churches encourage activities that involve the whole family, such as trips and celebrations, helping to promote interactions between parents and their children (MULLER; ELLISON, 2001; HEILBORN; BARROS; DUARTE, 2007). These connections can also, for example, restrict these adolescents and young people's free time, which may positively and indirectly affect various behavioral risks faced by these groups (REGNERUS, 2003).

The last factor mentioned by Smith, extra-community links, can be a positive source of religious influence on young people's lives because religion is very often connected to national and transnational religious organizations. Such links can provide valuable access to events and experiences that can expand the youths' aspirations, encouraging their development, restricting their free time, and exposing them to new knowledge (SMITH, 2003), which may indirectly affect their sexual behavior as well.
Little attention has been given to the possible impact of religious involvement on social and organizational ties in Brazil. Nevertheless, it is known that members of Pentecostal Protestant and Catholic charismatic churches usually experience close relationships with fellow believers. After their conversion, they usually join small prayer groups, which are called communities and resemble extended families. These communities teach, encourage, and challenge new adherents to seek greater spiritual growth and to construct stronger relationships (CLEARY, 2007).

Furthermore, Pentecostal Protestant churches in Brazil are recognized for promoting self-help networks that are national in scope. They usually offer not only psychological and spiritual, but also financial support, opening their homes to people in need, trying to help others find jobs, or even offering childcare support (BURDICK, 1993; MARIZ, 1994; CHESNUT, 2003; WOOD; WILLIAMS; CHIJIWA, 2007).

Figure 1 summarizes the conceptual model of how religion may directly and indirectly affect adolescent behaviors. It is based on Smith's (2003) theoretical framework on how religion would influence American adolescents. Because this article is particularly interested in such influence on adolescent sexual behavior, we added two important ways through which religion may affect Brazilian adolescents: religious sanctions and consequences for deviance.

Finally, it is worth noting the existence of many other theories that consider the roles of subjective rationales and norms to improve the understanding of sexual and reproductive behavior. Such approaches, which do not usually take into account the potential religious influence, may be particularly important to elucidate indirect influences on this behavior. The study of Juarez (1998), for instance, summarizes the most significant theories, especially from the field of psychology, for the identification of socio-cognitive determinants relevant to the practice of safer sex. Some of these

\footnotetext{
${ }^{3}$ Crente means believer, and it is a name popularly given to adepts of Protestant churches.
} 
FIGURE 1

Conceptual model of how religion may, directly and indirectly, affect adolescent sexual behavior

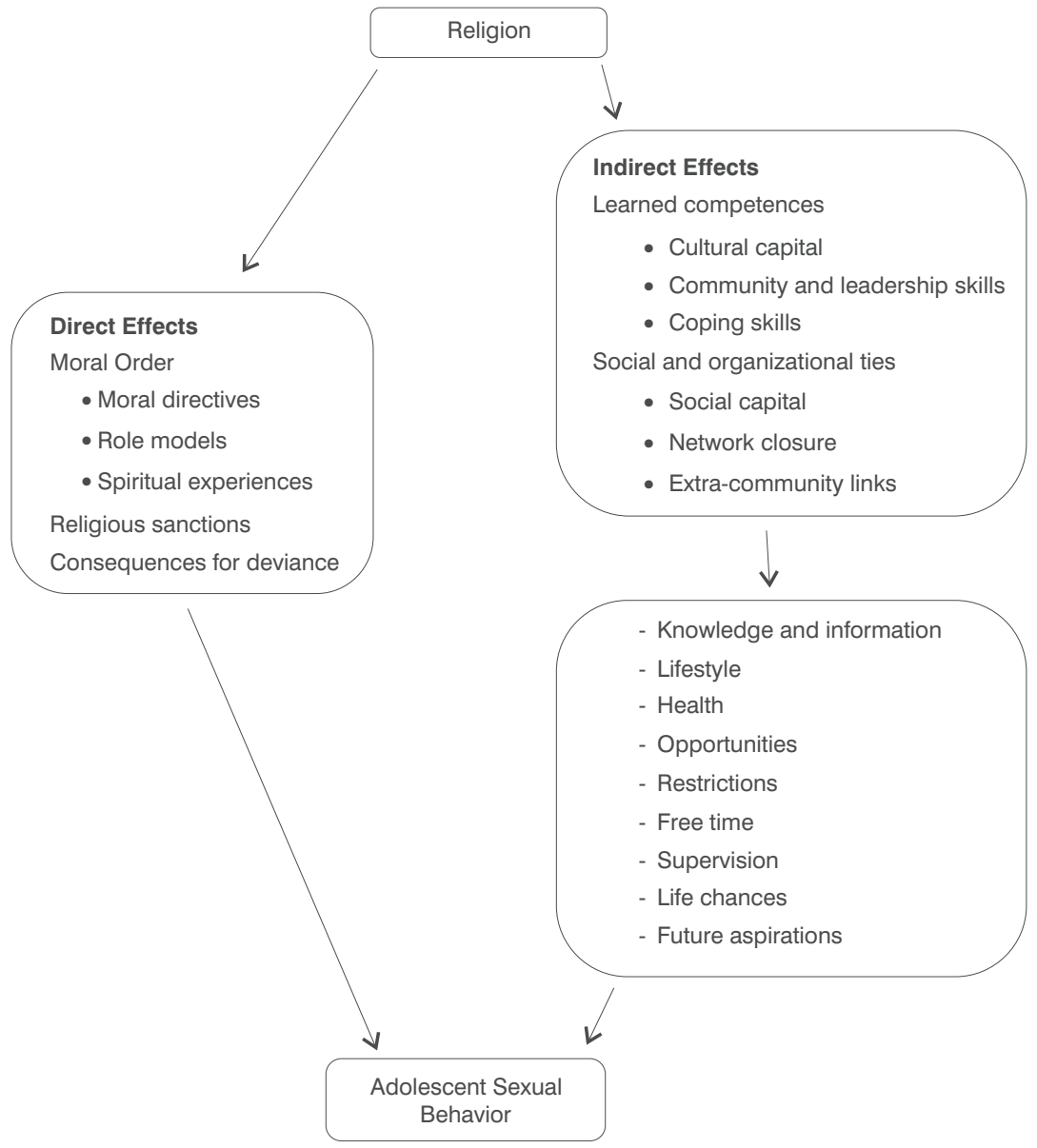

theoretical approaches incorporate factors such as locus of control (perception of control people believe they have over their lives) and self-esteem as predictors of sexual behavior (JUAREZ, 1998). Additionally, the approach called the theory of interactional suggests the role of the interactional process that includes, for example, the perception of social norms and social support, in determining sexual and reproductive behavior (JUAREZ, 1998).

\section{Discussion}

Religion is becoming an important and highly present factor in the lives of many adolescents and young adults in Brazil. In terms of attempting to attract this age group, Pentecostal churches and Catholic charismatic communities stand out, as they have used their resources to create a space for their young followers to participate actively in a religious environment. Youth groups, dating groups, trips, trade courses, lectures, and aid work in poor communities, among other activities, have been frequently observed in Protestant churches. In charismatic Catholic communities, or in traditional Catholic churches that are under the charismatic influence, youth groups, confirmation and other activities such as retreats and some specific courses 
are the dominant activities for youths. It is likely that both these churches and communities have been successful at creating indirect mechanisms through which religion can influence the lives and behavior of adolescents and young people in Brazil.

With the growth of Pentecostalism and the charismatic Catholic movement over the last few decades in Brazil, conservative norms related to the sexual behavior of adolescents and unmarried youth began to play an important and systematic role in the lives of the young converted. Then, in addition to offering greater space for youths to maintain close relationships, these religious transformations have promoted the dissemination of clearer standards and objectives, as well as punitive sanctions, with respect to the sexual behavior of their young followers.

The main objective of this article was to make a connection between the theoretical framework of Smith (2003) and ethnographic as well as quantitative studies conducted in Brazil about potential effects of religion on social and demographic outcomes. Although Smith (2003) did not try to explain specific outcomes of adolescents' lives, this article sought to investigate whether the mechanisms of religious influence structured by him may help to examine adolescents' sexual behavior. Importantly, this study suggests that although Smith's theory focuses on religious effects among American adolescents, each of its pathways can also be used to explain potential effects of religion on the lives of

\section{References}

ALVES, J. E. D.; NOVELLINO, M. S. A dinâmica das filiações religiosas no Rio de Janeiro: 1991-2000 - um recorte por educação, cor, geração e gênero. In: PATARRA, N.; AJARA, C.; SOUTO, J. O Rio de Janeiro continua sendo... Rio de Janeiro: Ence/IBGE, 2006, p. 275-308.

\section{ANTONIASSI, A. Por que o panorama religioso no Brasil mudou tanto? São Paulo: Paulus, 2006.}

BERQUÓ, E. S.; CAVENAGHI, S. M. Increasing adolescent and youth fertility
Brazilian adolescents too. Even though there is limited empirical evidence as to how the mechanisms of religious involvement work in Brazil, some Protestant churches and Catholic charismatic communities, as suggested earlier, may offer an appropriate environment for the emergence of some of the pathways suggested here. However, further research is necessary to better understand the way these mechanisms work in Brazil, especially those associated with the indirect effects of religion.

This research focused on positive effects of religious involvement on adolescent sexual behavior, such as later sexual experience and lower risks of adolescent childbearing. Nevertheless, it is important to highlight that negative results of religious participation can also take place - for example, it is suggested that when a church discourages the use of condoms, it might lead to an increase in the spread of HIV and other sexually transmitted diseases.

Finally, this research should encourage empirical studies on religion or religious involvement and adolescent sexual outcomes in Brazil. Besides the importance of examining the potential impacts of the recent religious transformations on demographic phenomena, this topic deserves further consideration from Brazilian demographers because, as pointed out by Regnerus (2007), religion is a primary socialization agent for adolescents and sexual activity is a sphere of human behavior of high importance in its religious applicability.

in Brazil: a new trend or a one-time event? Paper presented at the Annual Meeting of the Population Association of America, Philadelphia, Pennsylvania, March 30 to April 2, 2005.

BOURDIEU, P. The forms of capital. In: RICHARDSON, J. (Ed.). Handbook of Theory and Research for the Sociology of Education. New York: Greenwood, 1986, p. 241-258.

BRUSCO, E. The reformation of machismo. Austin: University of Texas Press, 1995. 
BURDICK, J. Looking for god in Brazil. Berkeley: University of California Press,1993.

CHESNUT, R. A. Born again in Brazil the Pentecostal boom and the pathogens of poverty. New Brunswick, NJ: Rutgers University Press, 1997.

CHESNUT, R. A. Competitive spirits - Latin America's new religious economy. New York: Oxford University Press, 2003.

CLEARY, E. L. The Catholic Charismatic renewal: revitalization movements and conversion. In: STEIGENGA, T. J.; CLEARY, E. L. (Eds.). Conversion of a continent: contemporary religious change in Latin America. Rutgers University Press, 2007, p. 153-173.

COCHRAN, J. The variables effects of religiosity and denomination on adolescent self-reported alcohol use by beverage type. Journal of Drug Issues, 23, p. 479-91, 1993.

COLEMAN, J. Social capital in the creation of human capital. American Journal of Sociology, 94, p. 95-120, 1988

CROCKETT, L. J.; BINGHAM C. R.; CHOPAK, J. S.; VICARY, R. Timing of first sexual intercourse: the role of social control, social learning, and problem behavior. Journal of Youth and Adolescence, 25, p. 89-111, 1996.

DECOL, R. D. Mudança religiosa no Brasil: uma visão demográfica. Revista Brasileira de Estudos de População, v. 16, n. 1/2, p. 121-137, 1999.

DELAMATER, J. The social control of sexuality. Annual Review of Sociology, 7, p. 263-290, 1981.

ELLISON, C. G.; LEVIN, J. S. The religionhealth connection: evidence, theory, and future directions. Health Education Behavior, 25, p. 700-720, 1998.

EVANS, T. D.; CULLEN, F.; DUNAWAY, R. G.; BURTON, V. Religion and crime reexamined: the impact of religion, secular controls, and social ecology on adult criminality. Criminology, 33, p. 195-217, 1995.

FESTINGER, L. A theory of cognitive dissonance. Stanford, CA: Stanford University Press, 1962.
GLANVILLE, J.; SIKKINK, D. E.; HERNÁNDEZ, E. Religious involvement and educational outcomes: the role of social capital and extracurricular participation. The Sociological Quarterly, 49, p. 105-137, 2008.

GODSCHEIDER; C.; MOSHER, W. D. Religious affiliation and contraceptive usage: Changing American patterns, 1955-82. Studies in Family Planning, v. 19, n. 1, p. $48-57,1988$.

GUPTA, N.; LEITE, I. C. Adolescent fertility behavior: trends and determinants in Northeastern Brazil. International Family Planning Perspectives, v. 25, n. 30, p. 125-130, 1999.

HARDY, S. A.; RAFFELLI, M. Adolescent religiosity and sexuality: an investigation of reciprocal influences. Journal of Adolescence, 26, p 731-739, 2003.

HEILBORN, M. L.; BARROS, M. L.; DUARTE, L. F. D. Família e religião. Rio de Janeiro: Contra Capa, 2007.

HILL, Z.; CLELAND, J.; ALI, M. Religious affiliation and extramarital sex among men in Brazil. International Family Planning Perspectives, v. 30, n. 1, p. 20-26, 2004.

HIRSCHI, T. Causes of delinquency. Berkeley: University of California Press, 1969.

HUMMER R. A; ELLISON, C. G.; ROGERS, R. G.; MOULTON, B. E.; ROMERO, R. R. Religious involvement and adult mortality in the United States: renew and perspectives. Southern Medical Journal, v. 97, n. 12, p. 1223-1230, 2004.

JUAREZ, F. Adolescent reproductive health in Latin América among low-income group. Paper presented in Seminar Poverty, Fertility and Family Planning. CICREDIISUNAM-UNFPA, Mexico City, 1998.

KOENIG, H. G.; MCCULLOUGH, M. E; LARSON, D. B. Handbook of religion and health. Oxford: Oxford University Press, 2001.

KRAUSE, N.; ELLISON, E. The doubting process: a longitudinal study of the precipitants and consequences of religious doubt in older adults. Journal for the Scientific Study of Religion, v. 48, n. 2, p. 293-312, 2009. 
KRAUSE, N.; ELLISON, C.; WULFF, K. Church-based emotional support, negative interaction, and psychological wellbeing: findings from a national sample of presbyterians. Journal for the Scientific Study of Religion, v. 37, n. 4, p. 725-741, 1998.

MARIANO, R. Expansão pentecostal no Brasil: o caso da Igreja Universal. Estudos Avançados, v. 18, n. 52, p. 121-138, 2004.

MARIZ, C. Coping with poverty: Pentecostal and Christian Base Communities in Brazil. Philadelphia, PA: Temple University Press, 1994.

MCKINNON, S.; POTTER, J.; GARRARDBURNETT, V. Adolescent fertility and religion in Rio de Janeiro, Brazil in the year 2000: the role of Protestantism. Population Studies, v. 62, n. 3, p. 289-303, 2008.

MCQUILLAN, K. When does religion influence fertility? Population and Development Review, v. 30, n. 1, p. 25-56, 2004.

MIRANDA-RIBEIRO, P.; LONGO, L. A. F. B.; RIOS-NETO, E. L. G.; POTTER, J. E. Fecundidade na adolescência e religião em Belo Horizonte: um primeiro exercício. Revista Brasileira de Estudos de População, v. 26, n. 2, p. 305-308, 2009.

MOSHER, W. D.; HENDERSHOT, G. E. Religious affiliation and fertility of married couples. Journal of Marriage and the Family, v. 46, n. 3, p. 671-677, 1984.

MULLER, C.; ELLISON, C. Religious involvement, social capital, and adolescents' academic progress: evidence from the nation education longitudinal study of 1988 . Sociological Focus, v. 34, n. 2, p.155-183, 2001.

PARKERSON, D. H.; PARKERSON, J. A. Fewer children of greater spiritual quality: religion and the decline of fertility in nineteenth-century America. Social Science History, v. 12, n. 1, p. 49-70, 1988.

PIERUCCI, A. F. O. Igreja: contradições e acomodação - ideologia do clero católico sobre a reprodução humana no Brasil. São Paulo: Cebrap,1978.
PIERUCCI, A. F. O.; PRANDI, R. Religious diversity in Brazil: numbers and perspectives in a sociological evaluation. International Sociology, 15, p. 629-639, 2000.

POTTER, J.; AMARAL, E.; WOODBERY, R. The growth of Protestantism in Brazil and its impact on income, 1970-2000. In: Meetings of the Association for the Study of Religion, Economics, and Culture (ASREC), Washington, DC. 2009.

REGNERUS, M. D. Forbidden fruit - Sex and religion in the lives of american teenagers. New York: Oxford University Press, 2007.

Religion and positive adolescent outcomes: a review of research and theory. Review of Religious Research, v.44, n. 4, p. 394-413, 2003.

Shaping schooling success: religious socialization and educational outcomes in metropolitan public schools. Journal for the Scientific Study of Religion, v. 39, n.3, p. 363-370, 2000.

REGNERUS, M. D.; SMITH C. Selection effects in studies of religion influence. Review of Religious Research, v. 47, n. 1, p. 23-50, 2005.

ROHDEN, F. et al. Religião e iniciação sexual em jovens de camadas populares. In:HEILBORN, M. L.; DUARTE, L. F. D.; PEIXOTO, C.; BARROS, M. L. (Orgs.). Sexualidade, família e ethos religioso. Rio de Janeiro: Garamond, 2005.

ROHRBAUGH, J.; JESSOR, R. Religiosity in youth: a personal control against deviant behavior. Journal of Personality, 43, p. $136-155,1975$.

ROSTOSKY, S. S.; WILCOX, B. L.; WRIGHT, M. L., RANDALL, B. A. The impact of religiosity on adolescent sexual behavior: a review of the evidence. Journal of Adolescent Research, v. 19, n. 6, p. 677-697, 2004.

SMITH, C. Theorizing religious effects among American adolescents. Journal for the Scientific Study of Religion, v. 42, n. 1, p. 17-30, 2003.

THORNTON, A.; CAMBURN, D. Religious participation and adolescent sexual behaviors 
and attitudes. Journal of Marriage and the Family, 51, p. 641-653, 1989.

VALLE, E. A renovação carismática católica: algumas observações. Estudos Avançados, v. 18, n. 52, p. 97-107, 2004.

VERONA, A. P. A. Sexual initiation and religion in Brazil. Tese (Doutorado em Sociologia). University of Texas at Austin, 2010.

VERONA, A. P. A.; HUMMER, R.; DIAS JUNIOR, C. S.; LIMA, L. Infant mortality and mothers' religious involvement in Brazil. Revista Brasileira de Estudos de População, v. 27, n. 1, p. 59-74, 2010.

VERONA, A. P. A.; REGNERUS, M. Pentecostalism and sexual initiation in Brazil.
Paper presented at the Annual Meeting of the Population Association of America, Detroit, MI, 2009.

WESTOFF, C. F.; JONES, E. F. The end of the Catholic fertility. Demography, v. 16, n. 2, p. 209-217, 1979.

WIMBERLEY, D. Religion and role-identity: a structural symbolic interacttionist conceptualization of religiosity. Sociological Quarterly, 30, p. 125-142, 1989.

WOOD, C.; WILLIAMS, P.; CHIJIWA, K. Protestantism and child mortality in Northeast Brazil, 2000. Journal for the Scientific Study of Religion, v. 46, n. 3, p. 405-416, 2007.

\section{Resumo}

Explicações para a influência da religião no comportamento sexual de adolescentes no Brasil: efeitos diretos e indiretos

A religião tem se tornado um fator cada vez mais importante e presente na vida de muitos adolescentes e jovens no Brasil. Além de oferecer espaço para a manutenção de fortes interações e participação em um contexto religioso, algumas religiões têm promovido a disseminação de padrões e objetivos, bem como de sanções punitivas, em relação a muitos aspectos da vida dos seus seguidores mais jovens, incluindo o comportamento sexual. Assim, este estudo analisa como a religião pode afetar, direta e indiretamente, o comportamento sexual de adolescentes brasileiros. O principal objetivo é estabelecer uma conexão entre o referencial teórico de Christian Smith, que sugere vários mecanismos por meio dos quais a religião pode influenciar a vida de adolescentes norte-americanos, e estudos etnográficos conduzidos no Brasil e trabalhos quantitativos que investigam consequências sociais e demográficas da recente transformação religiosa que o país tem atravessado. Apesar de existirem poucas evidências empíricas sobre como os mecanismos sugeridos por Smith funcionam no Brasil, este estudo conclui que cada um deles pode ser usado para explicar potenciais efeitos da religião sobre o comportamento sexual de adolescentes brasileiros. Esta pesquisa pode incentivar a produção de estudos sobre este tópico no Brasil. Além da importância de analisar os impactos das recentes transformações religiosas no Brasil sobre os fenômenos demográficos, este tema merece uma análise mais cuidadosa por parte dos demógrafos brasileiros, já que a religião é um dos principais agentes de socialização de adolescentes e a atividade sexual é uma esfera do comportamento humano muito presente no campo religioso.

Palavras-chave: Religião. Comportamento sexual de adolescentes. Mecanismos de influência. Efeitos diretos e indiretos. 


\section{Resumen}

Explicaciones sobre la influencia de la religión en el comportamiento sexual de adolescentes en Brasil: efectos directos e indirectos

La religión se ha convertido en un factor cada vez más importante y presente en la vida de muchos adolescentes y jóvenes en Brasil. Además de ofrecer espacio para el mantenimiento de interacciones fuertes y participación en un contexto religioso, algunas religiones han promovido la diseminación de patrones y objetivos, así como sanciones punitivas, en relación con muchos aspectos de la vida de sus acólitos más jóvenes, incluyendo el comportamiento sexual. Por ello, este estudio analiza cómo la religión puede afectar, directa e indirectamente, el comportamiento sexual de adolescentes brasileños. El principal objetivo de este trabajo es establecer una conexión entre el marco teórico de Christian Smith, que sugiere varios mecanismos, a través de los cuales la religión puede influenciar la vida de adolescentes norteamericanos, estudios etnográficos desarrollados en Brasil, y trabajos cuantitativos que investigan consecuencias sociales y demográficas de la reciente transformación religiosa que el país ha atravesado. A pesar de que existan pocas evidencias empíricas sobre cómo los mecanismos sugeridos por Smith funcionan en Brasil, este estudio concluye que cada uno de ellos puede ser usado para explicar potenciales efectos de la religión sobre el comportamiento sexual de adolescentes brasileños. Esta investigación puede incentivar la producción de estudios sobre este tema en Brasil. Además de la importancia de analizar los impactos de las recientes transformaciones religiosas en Brasil sobre los fenómenos demográficos, este asunto merece un análisis más cuidadoso por parte de los demógrafos brasileños, ya que la religión es uno de los principales agentes de socialización de adolescentes y la actividad sexual es una esfera del comportamiento humano muy presente en el campo religioso.

Palabras-clave: Religión. Comportamiento sexual de adolescentes. Mecanismos de influencia. Efectos directos e indirectos. 